\title{
Phylogenetic relationships between Chondrilla L. species in European Russia based on plastid DNA sequencing
}

\author{
Alexandr Kashin ${ }^{1, *}$, Ivan Schanzer ${ }^{2}$, Tatyana Kritskaya $^{1}$, and Alena Parkhomenko $^{1}$ \\ ${ }^{1}$ Saratov State University, Botanic Garden, Saratov, 410012, Russia \\ ${ }^{2}$ Main Botanical Garden, Herbarium (MHA), Moscow, 127276, Russia
}

\begin{abstract}
The article examines the genetic diversity in 54 populations of 9 Chondrilla species (C. acantholepis, C. ambigua, C. brevirostris, $C$. canescens, C. graminea, C. juncea, C. laticoronata, C. latifolia, and $C$. pauciflora) in European Russia. Plastid DNA segments trnT-trnF are selected as markers. Reconstruction of evolutionary networks based on the principle of maximum parsimony reveals that the sample is divided into four groups, where group 1 is C. ambigua, $2-C$. brevirostris, $3-C$. laticoronata, $4-C$. acantholepis, C. canescens, C. graminea, C. juncea, and $C$. latifolia. The findings show that $C$. acantholepis, $C$. canescens, $C$. graminea, $C$. juncea and $C$. latifolia are to be treated as synonyms under the name of $C$. juncea.
\end{abstract}

\section{Introduction}

Chondrilla genus is comprised by approximately 30 species that form two subgeni and four sections [1]. The genus is wide spread in the steppes and deserts of Eurasia and North Africa. There are no less than 7 in vivo Chondrilla species in European Russia. Six of them - C. acantholepis Boiss., C. brevirostris Fisch. et Mey, C. canescens Kat. et Kir., C. graminea Bieb., $C$. juncea L., and C. latifolia Bieb.- belong to the section Chondrilla of the subgenus Chondrilla. The seventh species $-C$. ambigua Fisch. - belongs to the subgenus Brachyrynchus [1]. Lately, more C. laticoronata Leonova populations are being spotted [2, 3].

Currently, there is no consistency in representing the taxonomic structure of the Chondrilla genus. Apomictic reproduction that is highly characteristic of the Chondrilla species $[4,5]$ makes it problematic to single out the species and distinguish between them as well as causes contradiction in evaluating their rank and taxa's relationships. The embryological analysis and the analysis of seed productivity show that, out of all the studied species in European Russia, C. ambigua is the only obligate amphimictic species while all the remaining taxa $(C$. acantholepis, $C$. canescens, $C$. graminea, $C$. juncea, $C$. latifolia, C. brevirostris, and C. laticoronata) are facultative apomicts [3, 5].

\footnotetext{
* Corresponding author: kashinas2@yandex.ru
} 
The present paper attempts to identify the relationships between the Chondrilla species in Southern Russia, based on the plastid DNA sequencing.

\section{Materials and Methods}

\subsection{Sampling}

The specimens were collected from the natural populations of 9 Chondrilla species $(C$. acantholepis, $C$. ambigua, $C$. brevirostris, $C$. canescens, $C$. graminea, $C$. juncea, $C$. Laticoronata, C. latifolia, and C. pauciflora) in the Astrakhan, Volgograd, Penza, Samara, Saratov, and Ulyunovsk oblasts as well as the Rebublic of Kalmykia and the Republic of Crimea. Three plants were selected from every population.

\subsection{DNA Extraction and Sequencing}

DNA was extracted from the ligules (petal-like corollas) after they had been dried in silica gel, using NucleoSpin ${ }^{\circledR}$ Plant II (MACHEREY-NAGEL, Germany) according to the manufacturer's protocol.

Primers $a$ and $b, c$ and $d, e$ and $f$ were used to perform the amplification of the plastid DNA segments trnT-trnL and trnL-trnF, including the intron trnL [6].

Sequencing was carried out in the ABI PRISM $3130 \mathrm{XL}$ sequenator using the reagent kit BIG DYE TERMINATOR kit ver. 3.1 produced by the Sintol company (Moscow, Russia).

\subsection{Statistical Analysis}

The forward and reverse sequences were manually edited and aligned in BioEdit 7.0.5.3. program [7]. The haplotype extraction and building of rootless network employed the method of statistical parsimony in TCS v. 1.21 program [8]. Only the nucleotide recombinations were taken into account; the indels were considered missing data. In order to root the obtained network, the data were further subject to the Neighbor Joining analysis in the program SplitsTree4 ver. 4.11.3[9]. An outgroup was comprised of the DNA sequences of Helenium arizonicum S.F.Blake (DQ395174.1) and Giallardia comosa A.Gray (DQ395152.1) obtained from GenBank.

\section{Results and Discussion}

The associated alignment of the spacers $\operatorname{trn} T-\operatorname{trn} L$ and $\operatorname{trn} L-\operatorname{trn} F$ and the intron $\operatorname{trn} L$ included 1292 positions, 13 of which were variable (contained recombinations). Furthermore, the research identified the duplication of the TATTT fragment in all specimens excluding $C$. ambigua, $C$. pauciflora, and $C$. brevirostris; the deletion of GAAA fragment in all specimens except for C. ambigua, C. pauciflora, $C$. brevirostris, and $C$. laticoronata; and the duplication of ATTACAAAT fragment in all $C$ ambigua, $C$. brevirostris, $C$. pauciflora, and $C$. laticoronata specimens. The analysis in the TCS program allowed for uniting Chondrilla sequences in 15 haplotypes. To reconstruct haplotype genealogy, all haplotypes were mapped in one network (probability of parsimonious decision $>95 \%$ ) that included 26 haplotypes, 11 of which were absent in the sample and were hypothetical transitional haplotypes (Fig. 1 on the left). Topologically, 4 clades, or groups were singled out within the network; each group was constituted of the internal haplotype and the closest terminal haplotypes designated with letters and numbers. 
In order to root the network, the haplotypes' matrix was subject to the Neighbor Joining analysis; the sequences of Helenium arizonicum and Giallardia comosa performed as an outgroup. The topology of the philogentic tree and the topology of the network were completely corresponding to each other. However, the place of the hypothetical root remained undefined which, most likely, is explained by the absence of the haplotypes situated between the clade A and its sister clade constituted of all the remaining haplotypes.


Fig. 1. Maximum parsimonious haplotype network (on the left) built in the TCS program and the locations of the studied Chondrilla populations (on the right). The circles' sizes are proportional to the numbers of specimens with a given haplotype. The small empty circles represent missing haplotypes.

Geographical mapping of haplotypes revealed that the haplotypes are distributed in the clear-cut patterns (Fig. 1 on the right). Group A is constituted of all specimens of $C$. ambigua, C. brevirostris, C. laticoronata and the probable hybrid species $C$. brevirostris $\times$ ambigua, located in the Astrakhan oblast and Kalmykia. Group A also contains specimens of C. brevirostris and C. pauciflora from Western Kazakhstan. Also, 4 out of 5 C. ambigua populations included specimens that possessed only haplotype A sequences. Haplotype A3 was found in $C$. ambigua population located near the Volnoye village, Kharabalinsky rayon, Astrakhan oblast. Apart from specimens of $C$. ambigua, haplotype A was found in 4 out of $5 \mathrm{C}$. brevirostris populations and in 1 out of 3 C. laticoronata populations. Haplotype A1 was found only in C. brevirostis population in Astrakhan oblast and in $C$. laticoronata population in Western Kazakhstan, haplotype A2 - only in C. laticoronata populations in Astrakhan oblast. No single instance of polymorphism within local populations was revealed.

Haplogroups B, C, D and E are widespread in C. acantholepis, C. canescens, C. graminea, C. juncea, and C. latifolia populations and are not confined to any particular taxon.

Both the analysis of chloroplast ITS sequences and the earlier conducted analysis of nuclear ribosomal ITS sequences [10] show that there are two evolutionary routes within the studied sample. The first route is observed in C. ambigua and C. pauciflora, as well as in $C$. brevirostris and $C$. laticoronata that have the plastid haplotypes of the same group 
(A). The latter two species are characterized by high heterozygosity of the ITS sequences [10]. The second evolutionary route is represented by the species with the haplotype groups B-F. Based on ITS ribotypes, C. laticoronata and C. brevirostris, though possessing the same chloroplast haplotypes as $C$. ambigua, are drastically different from $C$. ambigua and completely heterozygous. Both facts provide strong evidence that $C$. laticoronata and $C$. brevirostris derived from the hybridization of $C$. ambigua with some other species that resulted in the formation of new stable apomictic clones.

In conclusion, there is no doubt that $C$. ambigua is an independent species. $C$. brevirostris and $C$. laticoronata are hybrid groups, the parental forms of which are missing in the sample. The obtained data prove that $C$. acantholepis, $C$. canescens, $C$. graminea, $C$. juncea, and $C$. latifolia are the specimens of one and the same species under the priority name of $C$. juncea.

This study was supported by the Russian Foundation for Basic Research (project \#15-04-04087)

\section{References}

1. T. G. Leonova, Chondrilla L., In : Flora of European Part of the USSR, Volume 8 (Nauka Publ., Leningrad, 1989)

2. P. F. Maevsky, Flora of the Middle Belt of the European Part of Russia (KMK Scientific Press Ltd., Moscow, 2014)

3. E. V. Ugolnikova, A. S. Kashin, A. O. Kondrateva, Izv. Sarat. Univ. Ser. Chem. Biol. Ecol. 17, 53-61 (2017)

4. P. J. van Dijk, Phil. R. Soc. Lond. B. 358, 1113-1121 (2003)

5. A. S. Kashin, A. O. Popova, I. S. Kochanova, E. V. Ugolnikova, Yu. A. Polyakova, Bot. Zhurnal 100, 828-840 (2015)

6. P. Taberlet, L. Gielly, G. Pautou, J. Bouvet, Plant Mol. Biol. 17, 1105-1109 (1991)

7. T. A. Hall, Nucl. Acids. Symp. Ser. 41, 95-98 (1999)

8. M. Clement, D. Posada, K. A. Crandall, Mol. Ecol. 9, 1657-1659 (2000)

9. D. H. Huson, D. Bryant, Mol. Biol. Evol. 23, 254-267 (2006)

10. A. S. Kashin, T. A. Kritskaya, A. S. Parkhomenko, A. O. Kondratyeva, N. A. Petrova, Proceedings of the Conference Dedicated to the 85th Anniversary of the Birth of V.N. Tikhomirov (MAKS Press, Moscow, 2017) 